\title{
Evaluation of cardiovascular complexities and quality of life related to health in Chinese patients with thyrotoxic heart disease secondary to toxic diffuse goiter.
}

\author{
Dacheng Yang ${ }^{*}$, Fengjun Liü, Teng Ma \\ Department of Cardiovasology, Tengzhou Central People's Hospital, Shandong, PR China \\ \#These authors contributed equally to this work
}

\begin{abstract}
The common reason behind the development of thyrotoxic heart disease is toxic diffuse goiter via hyperthyroidism. The effect of cardiovascular complexities and quality of life related to health in Chinese patients with thyrotoxic heart disease secondary to toxic diffuse goiter has been evaluated. During July 2013-June 2015 patients were diagnosed with thyrotoxic heart disease secondary to toxic diffuse goiter. Clinical assessment was performed at baseline and after restoration of euthyroid state follow-up. A questionnaire was created and used to study the quality of life related to health in them. Cohort study data for 73 patients was obtained. However, around half (35) of these patients with thyrotoxic heart disease secondary to toxic diffuse goiter were agreed to participate further in investigation of their quality of life related to health. The frequency of cardiovascular complexities before and after anti-thyroid therapy was recorded. A significant reduction in respective values was observed as: thyrotoxic cardiomyopathy (78\% vs. $24 \%)$, ventricular extrasystole (72\% vs. $7 \%$ ), systolic blood pressure (158 vs. 126; in $\mathrm{mm}$ ), diastolic blood pressure ( $85 \mathrm{vs} .68$; in $\mathrm{mm}$ ), congestive cardiac failure (68 vs. 18; in \%), resting heart rate (124 vs. 76; in bpm) and atrial fibrillation (71 vs. 19; in \%). In all the domains, improvement in quality of life related to health was observed. There is a strong association of reduction in cardiovascular complexities and of increment in quality of life related to health with respect to restoration of euthyroidism in Chinese patients.
\end{abstract}

Keywords: Cardiovascular complexities, Quality of life related to health, Thyrotoxic heart disease, Toxic diffuse goiter. Accepted on May 12, 2016

\section{Introduction}

Thyrotoxic heart disease has been classified as the development of various cardiovascular complexities which results because the excess of thyroid hormones affect peripheral vasculature and cardiac myocytes, directly. It could manifest as thyrotoxic cardiomyopathy, ventricular extrasystole, congestive cardiac failure, elevated resting heart rate, atrial fibrillation, arterial high blood pressure (bp), and cardiac hypertrophy [1-4]. The common cause behind thyrotoxic heart disease is toxic diffuse goiter (TDG) [5], which is associated with hyperthyroidism constituting up to $5 \%$ of all endocrine disorders in several countries [6,7]. Besides, the reason behind the development of psychiatric disorders is the deregulation of thyroid hormones and its influence on neurotransmitters through hyperthyroidism $[8,9]$.

Quality of life related to health (QLrH) includes anxiety and depression as prime dimensions along with other dimensions as pain, mobility, discomfort, self-care etc. A number of clinical studies have suggested that hyperthyroidism may lead to anxiety and depression [10-13]. Concurrently, anxiety and depression may lead to thyroid abnormalities [14,15] as well as it may lead to various cardiovascular-based risks or even to cardiovascular-based deaths [16] and thus it can be said that depression and cardiovascular-related results are interrelated and this has been established in recent past [17-21]. Even then, studies in which depression has been assessed by means of interview-validated questionnaires have not been explored much and thus the precise relationship between hyperthyroidism and depression remains unclear. QLrH diminish due to thyrotoxic heart disease along with TDG [22-24]. Anti-thyroid drugs and $\beta$-adrenergic receptor antagonists are the preferential action to deal with TDG in Europe and Southeast Asia [25,26] because they eliminated hyperthyroidism and normalized the cardiovascular dimensions along with as well as QLrH [27-29]. Several authors have reported the effect of QLrH in different patients with hyperthyroidism or cardiovascular complexities [22-24,30-32] but up to a limited extent and so far the features of TDG in Chinese patients are less known. Thus our study is the first study of its own kind to reveal the association of thyrotoxic 
heart disease secondary to TDG with specific focus on quality of life related to health in Chinese patients.

\section{Materials and Methods}

The ethical committee of Tengzhou Central People's Hospital (China) has approved the study and consent procedure. The name of chairperson of ethics committee was Fengchun Wang, the identification of ethical committee was 20153545431, the protocol number and data of approval is June 4th of 2013. Written consent of all the participants who participated in the study was taken.

The patients were diagnosed between July 2013 to June 2015. Total 1252 patients were diagnosed with TDG among 2687 patients suffering from hyperthyroidism. Only 93 patients were appeared with thyrotoxic heart disease and hence participated in our study. Finally follow-up data and clinical information for 73 patients were obtained. Of these, only 35 patients with thyrotoxic heart disease secondary to TDG were further participated in QLrH investigation section of our study. A criterion for inclusion of patients was set in which TDG was diagnosed only with thyroid hormone disease and overt hyperthyroidism. Except this, the rest of the patients suffering from several diseases such as lung/liver failures, cancer or other infectious disease, any kind of history of coronary thrombosis or cardiac failures, secondary arterial high blood pressure, or any other congenital cardiac defects were excluded. An anti-thyroid therapy (AtT) was applied to all the patients using carbimazole with titration regimen method. However, in order to treat cardiological complexities, patients were administered with three types of medicines such as angiotensin-converting enzyme (ACE) inhibitor (captopril), $\beta$ adrenergic receptor antagonist (atenolol) or angiotensin II receptor blocker (fimasartan) (Table 1). During this study the patients were diagnosed before AtT (at baseline) means when TDG was diagnosed and after the follow up means establishment of stable euthyroidism. Follow up with respect to thyroid based and cardiovascular based examinations and investigation of QLrH section have included these two assessments.

Table 1. Medical treatment of cardiological complexities before the antithyroid therapy (AtT) and after the follow-up.

\begin{tabular}{|c|c|c|c|c|c|}
\hline Medicine & & Captopril & & Atenolol & Fimasartan \\
\hline Medicine's action & & $\begin{array}{l}\text { Angiotensin-converting } \\
\text { inhibitor }\end{array}$ & enzyme & $\beta$-Adrenergic receptor antagonist & Angiotensin II receptor blocker \\
\hline \multirow[t]{2}{*}{ AtT (at baseline) } & Daily dosage* & $10 / 5-42$ & & $72 / 30-100$ & $45 / 10-55$ \\
\hline & $\mathrm{n}$ & $54(74 \%)$ & & $73(100 \%)$ & $4(5 \%)$ \\
\hline \multirow[t]{2}{*}{ AtT (after follow up) } & Daily dosage* & $5.2 / 2.8-6$ & & $39 / 14-52.2$ & 0 \\
\hline & $\mathrm{n}$ & $16(22 \%)$ & & $16(22 \%)$ & 0 \\
\hline
\end{tabular}

AtT is antithyroid therapy; ${ }^{*} \mathrm{mg}$, mean/range; $\mathrm{n}$ is number of patients under therapy

\section{Investigation of QLrH section}

A questionnaire based upon visual analogue score system (VASS) was set and used for the investigation of QLrH section. Briefly, the questionnaire was answered by patients with respect to six dimensions as anxiety, depression, pain, mobility, discomfort and self-care in five levels of problems as: Level 1 (for no problem), Level 2 (for slight problem), Level 3 (for moderate problem), Level 4 (for severe problem) and Level 5 (for extreme problem). The overall health status of patients was rated as zero for the worst health care and as hundred for the best health care, using the vertical VASS as per previous report [33].

\section{Diagnosis of toxic diffuse gland}

For this purpose, a minimum of two parameters from: diffuse goiter, thyroid eye disease, increased level of thyroidstimulating hormone (TSH) receptor antibodies (TRAb), thyroid peroxidase antibodies (TPOAb) accompanied with high concentrations of serum-free thyroid hormones such as triiodothyronine (free T3), its prohormone, thyroxine (free T4) and TSH $(<0.1 \mathrm{mIU} / \mathrm{L})$ was chosen in order to get biochemical evidence of overt hyperthyroidism in the patients which in turn established the diagnosis of TDG. The normal concentrations of TRAb and TPOAb were less than 1.61 IU/L and $32 \mathrm{kIU} / \mathrm{L}$, respectively. Cobas E 411 analyzer (Roshe Diagnostics $\mathrm{GmbH}$, Germany) was used for evaluation of thyroid by blood testing and physical examination. Besides, Sonoline Sienna (Siemens, Germany) was used for ultrasonography purpose with respect to evaluation of thyroid.

\section{Cardiovascular complexities assessment}

Heartbeat per minute (bpm) was manually evaluated at the radial artery and it was used to determine the resting heart rate. As per reported guidelines [34,35], thyrotoxic heart disease was confirmed in patients with manifestations of arterial high blood pressure, ventricular extrasystole, congestive cardiac failure, atrial fibrillation or thyrotoxic cardiomyopathy. However, manual digital BP monitor (Little Doctor, Singapore) was used to measure the office bp and mean of three was considered. The patients having systolic $b p \geq 140 \mathrm{~mm} \mathrm{Hg}$ and/or diastolic $\mathrm{bp} \geq 90 \mathrm{~mm} \mathrm{Hg}$ were considered as patients of arterial high bp. Electrocardiography was performed by $12-$ leads-3-channel ECG machine ECG300G (CONTEC, China). EnVisor C Ultrasound System (Philips, USA) was used for 
Evaluation of cardiovascular complexities and quality of life related to health in Chinese patients with thyrotoxic heart disease secondary to toxic diffuse goiter

echocardiography purpose as per previous report [36] in order to measure several parameters of the heart as shown in Table 2. Mosteller formula [37] was used to determine body surface area (BSA). With the assistance of body weight (in $\mathrm{kg}$ ) per height (in $\mathrm{m}^{2}$ ), body mass index (BMI) was calculated.

Table 2. Cardiovascular parameters assessments before and after the antithyroid therapy $(A t T)$ in the patients with toxic diffuse goiter

\begin{tabular}{|c|c|c|c|}
\hline & \multirow[t]{2}{*}{ Features } & \multicolumn{2}{|l|}{ Patients $(n=73)$} \\
\hline & & Before AtT & After AtT \\
\hline \multirow[t]{8}{*}{ Physiological features Assessment } & Heart rate, bpm & $124,122,95-195$ & $76,73,65-105$ \\
\hline & Mean, median, range & & \\
\hline & Systolic bp, mm Hg & $158,156,135-195$ & $126,125,75-160$ \\
\hline & Mean, median, range & & \\
\hline & Diastolic bp,mm Hg & $85,82,60-120$ & $68,66,55-80$ \\
\hline & Mean, median, range & & \\
\hline & Pulse bp, mm Hg & $73,70,45-115$ & $55,54,50-80$ \\
\hline & Mean, median, range & & \\
\hline \multirow[t]{10}{*}{ Heart sizes features Assessment } & Left ventricular mass, $\mathrm{g}$ & $230,228,120-375$ & $195,192,109-401$ \\
\hline & Mean, median, range & & \\
\hline & Left ventricular mass index, $\mathrm{g} / \mathrm{m} 2$ & $131,126,68-227$ & $108,101,58-221$ \\
\hline & Mean, median, range & & \\
\hline & Left atrium dimension, $\mathrm{cm}$ & & \\
\hline & Mean, median, range & $4.1,3.9,3.3-5.8$ & $3.8,3.6,3.2-4.8$ \\
\hline & $\begin{array}{l}\text { Interventricular septum wall thickness, } \\
\mathrm{cm}\end{array}$ & $1.3,1.2,0.9-1.5$ & $1.2,0.9,0.9-1.4$ \\
\hline & Mean, median, range & & \\
\hline & Posterior septum wall thickness, $\mathrm{cm}$ & & \\
\hline & Mean, median, range & $1.3,1.1,0.9-1.5$ & $1.2,0.7,0.9-1.5$ \\
\hline \multirow[t]{17}{*}{ Left Ventricular features Assessment } & End-systolic diameter, cm & & \\
\hline & Mean, median, range & $3.8,3.6,2.8-4.6$ & $3.4,3.4,2.7-5.9$ \\
\hline & End-diastolic diameter, $\mathrm{cm}$ & & \\
\hline & Mean, median, range & $5.4,5.2,4.3-6.4$ & $4.8,4.9,3.9-5.9$ \\
\hline & End-systolic volume, $\mathrm{mL}$ & & \\
\hline & Mean, median, range & $52,53,29-96$ & $42,41,22-66$ \\
\hline & End- diastolic volume, $\mathrm{mL}$ & & \\
\hline & Mean, median, range & $145,146,95-190$ & $127,127,85-170$ \\
\hline & Relative wall thickness, $\mathrm{cm}$ & & \\
\hline & Mean, median, range & $0.7,0.7,0.4-0.9$ & $0.6,0.6,0.4-1.7$ \\
\hline & *Geometry, n= & & p-value \\
\hline & Normal geometry & $2(3 \%)$ & $10(14 \%) 0.030$ \\
\hline & Concentric hypertrophy & $54(74 \%)$ & $28(38 \%)<0.001$ \\
\hline & Eccentric hypertrophy & $4(5 \%)$ & $12(16 \%) 0.111$ \\
\hline & Concentric remodeling & $16(22 \%)$ & $25(34 \%) 0.201$ \\
\hline & Ejection fraction, \% & $65,65,47-80$ & $68,67,58-84$ \\
\hline & Mean, median, range & & \\
\hline
\end{tabular}

BP: Blood Pressure; *For all other cases $p$-value $<0.001$. 


\section{Statistical analysis}

For univariate statistical analysis purpose, the Statistica software system (version 12.0, StatSoft Scandinavia AB, Sweden) was used. In order to evaluate the studied parameters' differences two-tailed Fisher's exact test and Wilcoxon signedrank test were applied and the statistical significance was set to $\mathrm{p}<0.01$. The STATA/SE software system (version 13.0, StataCorp, TX, USA) was used to perform the regression analysis. The correlation of various factors such as age, systolic BP, TSH, BMI, free T3, TPOAb, free T4, TRAb, with respect to variations in left ventricular geometry in both analyses was tested in the linear regression. The $p$-value $<0.05$ was taken as statistically significant criterion for the results.

\section{Results}

\section{Clinical assessments outcomes with respect to}

Physical features: The detailed outcomes of clinical assessment of patients before (means at baseline) and after (means after follow up) anti-thyroid therapy (AtT) are shown in Table 3. Total 70\% (51) women and 30\% (22) men of 50 years old (mean age with range 32-66) were present among 73 patients. They were followed up for 6 months after the diagnosis (range 4-12). The respective values of BMI, BSA and mean body weight were $72 \mathrm{~kg}, 24.8 \mathrm{~kg} / \mathrm{m}^{2}$ and $1.78 \mathrm{~m}^{2}$ at the time of diagnosis and after the AtT they changed to $74 \mathrm{~kg}$, $26.1 \mathrm{~kg} / \mathrm{m}^{2}$ and $1.84 \mathrm{~m}^{2}$, respectively.

Hyperthyroidism features: Assistance of ultrasonography was taken and detected that around 93\% (68) patients had enlarged thyroid, at baseline. Size of thyroid of left lobe and right lobe were $44 \mathrm{~cm}^{3}$ and $48 \mathrm{~cm}^{3}$, respectively. After AtT, significant increase in their respective volumes $\left(60 \mathrm{~cm}^{3}\right.$ and 65 $\mathrm{cm}^{3}$ ) was observed. Thyroid eye disease was shown in 52 (71\%) patients at baseline and in $14(19 \%)$ patients after AtT. Low concentrations of TSH $(0.025 \mathrm{mIU} / \mathrm{L}$, mean $)$ confirmed the presence of hyperthyroidism but a significant increase in it (up to $3.1 \mathrm{mIU} / \mathrm{mL}$ ) after AtT was seen. The values of thyroid hormones concentrations before and after AtT of free T3 (28.6 vs. $6.1 \mathrm{pmol} / \mathrm{L})$, free T4 (82.9 vs. $16.4 \mathrm{pmol} / \mathrm{L})$ suggested that all the patients exhibited overt hyperthyroidism and then restored to euthyroid state. Besides, increase in TSH concentrations (more than $0.1 \mathrm{mIU} / \mathrm{L}$ ) in $59(81 \%)$ patients after AtT was also observed and thus supported the decrease in free T3 and T4 concentrations. Thus it can also be said that 14 (19\%) patients were diagnosed with a subclinical hyperthyroidism without clinical manifestations. On the other hand, thyroid autoantibodies: TRAb (108 vs. 29 IU/L), TPOAb (291 vs. $120 \mathrm{kIU} / \mathrm{L}$ ), showed similar trend of decrease in their concentrations after AtT.

Table 3. Clinical assessments of the patients before and after the antithyroid therapy (AtT).

\begin{tabular}{lll}
\hline Features & \multicolumn{2}{l}{ Patients $(n=73)$} \\
\cline { 2 - 3 } & Before AtT $\quad$ After AtT \\
\hline
\end{tabular}

\begin{tabular}{|c|c|c|c|c|}
\hline \multirow{6}{*}{$\begin{array}{l}\text { Physical features } \\
\text { Assessment }\end{array}$} & \multicolumn{4}{|l|}{ Weight, kg } \\
\hline & Mean, median, range & \multicolumn{2}{|c|}{$72,70,48-112$} & $74,71,53-116$ \\
\hline & \multicolumn{4}{|l|}{$\mathrm{BMI}, \mathrm{kg} / \mathrm{m}^{2}$} \\
\hline & Mean, median, range & $\begin{array}{l}24.8 \\
15.6-36.5\end{array}$ & 23.9 & $\begin{array}{l}26.1, \quad 25.2, \\
15.6-40.6\end{array}$ \\
\hline & \multicolumn{4}{|l|}{$\mathrm{BSA}, \mathrm{m}^{2}$} \\
\hline & Mean, median, range & $\begin{array}{l}1.78 \\
1.5-2.2\end{array}$ & 1.75 & $\begin{array}{l}1.84 \\
1.6-2.3\end{array}$ \\
\hline \multirow{15}{*}{$\begin{array}{l}\text { Hyperthyroidism } \\
\text { features } \\
\text { Assessment }\end{array}$} & \multicolumn{4}{|l|}{ Size of thyroid, $\mathrm{cm}^{3}$} \\
\hline & $\begin{array}{l}\text { Left lobe (Mean, } \\
\text { median, range) }\end{array}$ & \multicolumn{2}{|c|}{$44,30,10-180$} & $60,43,11-210$ \\
\hline & $\begin{array}{l}\text { Right lobe (Mean, } \\
\text { median, range) }\end{array}$ & \multicolumn{2}{|c|}{$48,30,14-210$} & $65,54,14-225$ \\
\hline & \multicolumn{4}{|l|}{ Thyroid eye disease } \\
\hline & Yes/No & \multicolumn{2}{|c|}{$\begin{array}{l}52 \quad(71 \%) \quad / 21 \\
(29 \%)\end{array}$} & $\begin{array}{l}14 \quad(19 \%) \quad / 59 \\
(81 \%)\end{array}$ \\
\hline & \multicolumn{4}{|l|}{$\mathrm{TSH}, \mathrm{mIU} / \mathrm{L}$} \\
\hline & Mean, median, range & $\begin{array}{l}0.025, \quad 0 \\
0.003-0.07\end{array}$ & 0.006 & $\begin{array}{l}3.1, \\
0.006-54.7\end{array}$ \\
\hline & \multicolumn{4}{|l|}{ Free T3, pmol/L } \\
\hline & Mean, median, range & $\begin{array}{l}28.6 \\
4.8-56\end{array}$ & 26.2 & $6.1,5.8,3.2-9.6$ \\
\hline & \multicolumn{4}{|l|}{ Free T4, pmol/L } \\
\hline & Mean, median, range & $\begin{array}{l}82.9 \\
26.6-330\end{array}$ & 80 & $\begin{array}{l}16.4 \\
1.4-34\end{array}$ \\
\hline & \multicolumn{4}{|l|}{ TRAb, IU/L } \\
\hline & Mean, median, range & $\begin{array}{l}108 \\
0.9-3581\end{array}$ & 35 & $29,14,0.9-312$ \\
\hline & \multicolumn{4}{|l|}{ TPOAb, kIU/L } \\
\hline & Mean, median, range & $\begin{array}{l}291 \\
5.9-6022\end{array}$ & 147 & $\begin{array}{l}120 \\
5.2-1145\end{array}$ \\
\hline
\end{tabular}

\section{Cardiovascular parameters assessments outcomes}

Physiology, heart sizes and left ventricular features: Table 2 shows noteworthy gains in cardiovascular physiology, heart sizes and left ventricular parameters after AtT. Physiological analyses showed decrease in heart rate (from 124 to $76 \mathrm{bpm}$ ), systolic bp (from 158 to $126 \mathrm{~mm} \mathrm{Hg}$ ) and diastolic bp (from 85 to $68 \mathrm{~mm} \mathrm{Hg}$ ) after AtT. Similarly, heart sizes showed significant decrease in terms of mass (from 230 to $195 \mathrm{~g}$ ) and mass index (from 131 to $108 \mathrm{~g} / \mathrm{m} 2$ ) of left ventricular, dimension of left atrium (from 4.1 to $3.8 \mathrm{~cm}$ ) and septum wall thickness of interventricular and posterior (from 1.3 to $1.2 \mathrm{~cm}$ ) after AtT. Besides, most left ventricular parameters also showed decrease in diameters and volumes in both the endsystolic (from 3.8 to $3.4 \mathrm{~cm}$; from 52 to $42 \mathrm{~mL}$, respectively) and in end-diastolic (from 5.4 to $4.8 \mathrm{~cm}$; from 145 to $127 \mathrm{~mL}$, respectively) features after AtT while rest left ventricular parameters showed increase in terms of geometry and ejection fraction after AtT (Table 2). 
Evaluation of cardiovascular complexities and quality of life related to health in Chinese patients with thyrotoxic heart disease secondary to toxic diffuse goiter

Rhythmic disorders: A decrease in cardiac rhythm disorders (Table 4) in euthyroid patients (i.e. after AtT) was observed when the cardiovascular parameters in terms of pulmonary high bp (from $16(22 \%)$ to $4(6 \%)$ ), arterial high bp (from 69 $(95 \%)$ to $2(2 \%))$, thyrotoxic cardiomyopathy (from $57(78 \%)$ to $18(24 \%)$ ), atrial fibrillation (from $52(71 \%)$ to $14(19 \%)$ ), congestive cardiac failure (from $50(68 \%)$ to $13(18 \%)$ ) and ventricular extrasystole (from $53(72 \%)$ to $5(7 \%)$ ) were further analyzed.

Table 4. Assessments of cardiac rhythm disorders secondary to toxic diffuse goiter before and after the antithyroid therapy (AtT).

\begin{tabular}{lll}
\hline \multirow{2}{*}{ Features } & \multicolumn{1}{l}{ Patients ( $\mathrm{n}=73)$} & \\
\cline { 2 - 3 } & Before AtT & After AtT \\
\hline Pulmonary high bp & & \\
\hline Yes/No & $16(22 \%) / 57(78 \%)$ & $4(6 \%) / 69(94 \%)$ \\
\hline Arterial high bp & $69(95 \%) / 4(5 \%)$ & $2(2 \%) / 71(82 \%)$ \\
\hline Yes/No & $57(78 \%) / 16(22 \%)$ & $18(24 \%) / 55(76 \%)$ \\
\hline Thyrotoxic cardiomyopathy & & \\
\hline Yes/No & $52(71 \%) / 21(29 \%)$ & $14(19 \%) / 59(81 \%)$ \\
\hline Atrial fibrillation & & \\
\hline Yes/No & $50(68 \%) / 23(32 \%)$ & $13(18 \%) / 60(82 \%)$ \\
\hline Congestive cardiac failure & & \\
\hline Yes/No & & $5(7 \%) / 68(93 \%)$ \\
\hline Ventricular extrasystole & & \\
\hline Yes/No & $53(72 \%) / 20(28 \%)$ & 5 \\
\hline
\end{tabular}

For all the cases $p$-value $<0.001$

\section{Left ventricular geometry outcomes}

Table 2 showed the detection of all types of left ventricular geometry in our study cohort. A normal left ventricular geometry was diagnosed in $2(3 \%)$ patients at baseline, while it was changed to $10(14 \%)$ patients after AtT $(\mathrm{p}=0.030)$. But a significant reversal was observed in the case of concentric hypertrophy (from $54(74 \%)$ to $28(38 \%)$; p-value $<0.001)$ thus the normalization of left ventricular mass was observed. Only $\mathrm{TRAb}$ could predict the changes in left ventricular geometry features during univariate analysis b-coefficient $=0.028(95 \%$ CI 0.00-0.07). Similar type of noteworthy association between $\mathrm{TRAb}$ and changes in left ventricular geometry features was also observed in multivariate analysis. Other factors had no noteworthy association in both the analysis (data not shown).

\section{Effect of AtT on QLrH}

Noteworthy gains of QLrH were observed in all the six dimensions as shown in Table 5 and Figure 1. Our analysis showed that after AtT the problems related to anxiety (34 (97\%) vs $22(63 \%))$ and depression (33 (95\%) vs. $23(65 \%))$ eliminated in around $30 \%$ patients $(\mathrm{p}<0.005)$. Similar pattern was shown by analyses of problems related to pain (34 (97\%) vs. $22(63 \%))$ and discomfort $(33(95 \%)$ vs. $23(65 \%))$ after AtT. However, after the treatment, $8(23 \%)$ and $14(40 \%)$ patients reported elimination of problems related to self-care and mobility dimensions, respectively, which is respectively thrice and twice less frequent as compared to $23(65 \%)$ and 30 $(85 \%)$ cases before AtT.

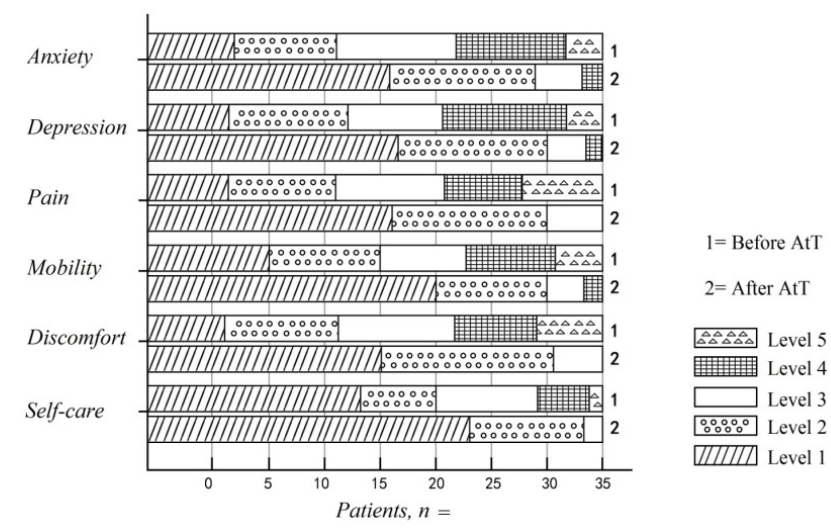

Figure 1. Representative diagram of the questionnaire answered by patients with respect to six dimensions as anxiety, depression, pain, mobility, discomfort and self-care in five levels from 1 to 5 for no problem, slight problem, moderate problem, severe problem and extreme problem, respectively, for the assessment of QLrH.

Table 5. Assessments of quality of life related to health (QLrH) using our questionnaire before and after the antithyroid therapy $(A t T)$.

\begin{tabular}{lll}
\hline Features & Patients (n=35) & \\
\cline { 2 - 3 } & Before AtT & After AtT \\
\hline Anxiety problems* & $34(97 \%) / 1(3 \%)$ & $22(63 \%) / 13(37 \%)$ \\
\hline Yes/No & & \\
\hline Depression problems* & $33(95 \%) / 2(5 \%)$ & $23(65 \%) / 12(35 \%)$ \\
\hline Yes/No & $34(97 \%) / 1(3 \%)$ & $22(63 \%) / 13(37 \%)$ \\
\hline Pain problems & $30(85 \%) / 5(15 \%)$ & $14(40 \%) / 21(60 \%)$ \\
\hline Yes/No & & \\
\hline Mobility problems & & \\
\hline Yes/No & $33(95 \%) / 2(5 \%)$ & $23(65 \%) / 12(35 \%)$ \\
\hline Discomfort problems & & \\
\hline Yes/No & & \\
\hline Self-care problems & & \\
\hline Yes/No & & \\
\hline p-value 0.004; for all other cases p-value<0.001 & \\
\hline
\end{tabular}

\section{Discussion}

Thyrotoxic heart disease associated cardiovascular complexities and QLrH through hyperthyroidism in Chinese patients diagnosed with TDG were investigated. A strong association between the omission of cardiovascular disorders 
and gains in QLrH and the restoration of the euthyroid state was found. Broadly speaking, thyrotoxic heart disease secondary to toxic diffuse goiter was analyzed in order to set up relationship between cardiovascular symptoms and QLrH. It was established that TDG has significant impact on development related to cardiovascular complexities and also on the normalization of cardiac functions at the euthyroid state and this result is quite consistent to the previous works $[3,7,8,30]$. Since thyroid hormones directly affect the sinoatrial node [38], it might be the reason for our finding that the resting heart rate in all patients was elevated before AtT and it is commonly reported as rhythmic disorders in patients of TDG. In the line with other reports $[39,40]$, a reversal of ventricular extrasystole and atrial fibrillation to normal rhythm of the heart after the restoration of euthyroidism was also found.

It was diagnosed that more than half of the patients with damaged QLrH and hyperthyroidism had congestive cardiac failure and atrial fibrillation and thus these disorders had no negative impact on QL. The diagnosis results of remodeling of left ventricular geometry and thyrotoxic cardiomyopathy secondary to TDG before AtT is in agreement with a previous report [7]. Our findings suggest that the anti-thyroid drugs play an essential role in early detection and treatment of hyperthyroidism which leads to prevention and reversibility of thyrotoxic cardiomyopathy, as reported elsewhere [7]. Reversal of concentric hypertrophy to left ventricular geometry of various types as well as noteworthy gains of other left ventricular parameters was also observed. Arterial high bp was diagnosed in $95 \%$ of patients and which lead to high systolic bp because excess of thyroid hormones is responsible for elevation in the resting rate of heart and volume of blood [38]. The association between diminished QLrH and arterial high bp secondary to TDG was also shown. Earlier reports $[7,38,39]$ showed major impact of the excess of thyroid hormones on the cardiomyocytes and thus the favorable effect of $\beta$-adrenergic receptor antagonists' and ACE inhibitors' gain of left ventricular remodeling $[41,42]$ have supported our work of restoration of euthyroid state. Thus it could be hypothesized that even in relatively short follow up time cardiovascular parameters might show improvement when euthyroidism was restored using $\beta$-adrenergic receptor antagonists and $\mathrm{ACE}$ inhibitors based AtT. In majority of patients, the thyroid autoantibodies TRAb and TPOAb were found. It was also determined that TRAb was an independent predictor of changes in left ventricular geometry but its impact on left ventricular geometry was specifically indirected by stimulating the synthesis of thyroid hormones and thus subsequently affected the cardiomyocytes [3].

Assessment of QLrH with our questionnaire showed decreasing of physical activity dimensions (i.e. mobility and self-care problems) followed by their noteworthy gains after AtT. These problems happened in hyperthyroid patients due to dramatic increase in cardiac work which in turn leads to low ability for adequate response to exercises and myocardial hypertrophy. High frequency of problems related to anxiety, depression, pain and discomfort dimensions which is previously reported in patients of hyperthyroidism, subclinical hyperthyroidism and TDG $[9,29]$ was also found. In the line of previous reports $[9,29,38]$ association of stabilization of hemodynamic parameters, elimination of thyrotoxic heart disease in around $30 \%$ of patients and reduction in the problems in majority of patients was achieved even when the volume of goiter was increased after AtT. Besides, an association between significant reduction of anxiety and depression dimensions and elimination of hyperthyroidism was also found as reported elsewhere [27-29]. These two dimensions had negative impact on QLrH in patients with thyrotoxic heart disease but these disorders were diminished after euthyroidism restoration. In order to existence of pathophysiological relation between neurotransmitter based mental health and the excess of thyroid based hormones, the scientific community found the presence of these two mood disorders in hyperthyroid patients as a common report [8,9]. The only limitation to our study is that relatively less numbers of participants were used even then our results lie in the line of those studies which used larger numbers of participants [7,30,39].

In conclusion, it can be said that it is the first ever report of evaluation of QLrH in Chinese patients with thyrotoxic heart disease secondary to TDG. Our analyses have discovered the hyperthyroidism's influence on the health of patients followed by noteworthy gain in QLrH as well as the omission of cardiovascular complexities due to thyrotoxic heart disease by subsequent normalization of thyroid hormones concentrations in greater number of patients.

\section{References}

1. Saito I, Ito K, SarutaT. The effect of age on blood pressure in hyperthyroidism. J Am Geriatr Soc 1985; 33: 19-22.

2. Jernfors M, Valimaki MJ, Setala K, Malmberg H, Laitinen K, Pitkaranta A. Efficacy and safety of orbital decompression in treatment of thyroid-associated ophthalmopathy: long-term follow-up of 78 patients. Clin Endocrinol 2007; 67: 101-107.

3. Dahl P, Danzi S, Klein I. Thyrotoxic cardiac disease. Curr Heart Fail Rep 2008; 5: 170-176.

4. Faber J, Selmer C. Cardiovascular disease and thyroid function. Front Horm Res 2014; 43: 45-56.

5. Bartalena L. Graves' Orbitopathy: Imperfect Treatments for a Rare Disease. Eur Thyroid J 2013; 2: 259-269.

6. Elberling TV, Rasmussen AK, Feldt-Rasmussen U, Hording M, Perrild H, Waldemar G. Impaired healthrelated quality of life in Graves' disease. A prospective study. Eur J Endocrinol 2004; 151: 549-555.

7. Oliveros-Ruiz L, Vallejo M, Diez Canseco LF, Cardenas M, Hermosillo JA. Determinants of thyrotoxic cardiomyopathy recovery. Biomed Res Int 2013; 2013: 452709.

8. Buras A, Battle L, Landers E, Nguyen T, Vasudevan N. Thyroid hormones regulate anxiety in the male mouse. Horm Behav 2014; 65: 88-96.

9. Gulseren S, Gulseren L, Hekimsoy Z, Cetinay P, Ozen C, Tokatlioglu B. Depression, anxiety, health-related quality of 
life, and disability in patients with overt and subclinical thyroid dysfunction. Arch Med Res 2006; 37: 133-139.

10. Bahls SC, de Carvalho GA. The relation between thyroid function and depression: a review. Rev Bras Psiquiatr 2004; 26: 41-49.

11. Duntas LH, Maillis A. Hypothyroidism and depression: salient aspects of pathogenesis and management. Minerva Endocrinol 2013; 38: 365-377.

12. Hage MP, Azar ST. The link between thyroid function and depression. J Thyroid Res 2012; 2012: 590648.

13. Kamble MT, Nandedkar PD, Dharme PV, Bhosale PG. Thyroid function and mental disorders: an insight into the complex interaction. J Clin Diagn Res 2013; 7: 11-14.

14. Berent D, Zboralski K, Orzechowska A, Galecki P. Thyroid hormones association with depression severity and clinical outcome in patients with major depressive disorder. Mol Biol Rep 2014; 41: 2419-2425.

15. Tsuru J, Shitobi Y, Ninomiya T, Kanehisa M, Managa J, Noue A, Okamoto S, Maruyama Y, Higuma H, Tanaka Y, Hanada H, Isogawa K, Akiyoshi J. The thyrotropinreleasing hormone test may predict recurrence of clinical depression within ten years after discharge. Neuroendocrinol Lett 2013; 34: 409-417.

16. Penninx BW, Milaneschi Y, Lamers F, Vogelzangs N. Understanding the somatic consequences of depression: biological mechanisms and the role of depression symptom profile. BMC Med 2013; 11: 129.

17. Watkins LL, Koch GG, Sherwood A, Blumenthal JA, Davidson JR, O'Connor C, Sketch MH. Association of anxiety and depression with all-cause mortality in individuals with coronary heart disease. J Am Heart Assoc 2013; 2: e000068.

18. Frasure-Smith N, Lesperance F. Depression and anxiety as predictors of 2-year cardiac events in patients with stable coronary artery disease. Arch Gen Psychiatry 2008; 65: 62-71.

19. Gump BB, Matthews KA, Eberly LE, Chang YF. Depressive symptoms and mortality in men: results from the multiple risk factor intervention trial. Stroke 2005; 36 : 98-102.

20. Ferketich AK, Schwartzbaum JA, Frid DJ, Moeschberger ML. Depression as an antecedent to heart disease among women and men in the NHANES I study. National Health and Nutrition Examination Survey. Arch Intern Med 2000; 160: 1261-1268.

21. Ford DE, Mead LA, Chang PP, Cooper-Patrick L, Wang NY, Klag MJ. Depression is a risk factor for coronary artery disease in men: the precursors study. Arch Intern Med 1998; 158: 1422-1426.

22. Abraham-Nordling M, Wallin G, Lundell G, Torring O. Thyroid hormone state and quality of life at long-term follow-up after randomized treatment of Graves' disease. Eur J Endocrinol 2007; 156: 173-179.

23. Abraham-Nordling M, Torring O, Hamberger B, Lundell G, Tallstedt L, Calissendorff J, Wallin G. Graves' disease: a long-term quality-of-life follow up of patients randomized to treatment with antithyroid drugs, radioiodine, or surgery. Thyroid 2005; 15: 1279-1286.

24. Al-Adhami A, Craig W, Krukowski ZH. Quality of life after surgery for Graves' disease: comparison of those having surgery intended to preserve thyroid function with those having ablative surgery. Thyroid 2012; 22: 494-500.

25. Weetman AP. Graves' disease. N Engl J Med 2000; 343: 1236-1248.

26. Abraham P, Avenell A, Park CM, Watson WA, Bevan JS. A systematic review of drug therapy for Graves' hyperthyroidism. Eur J Endocrinol 2005; 153: 489-498.

27. Denollet J, Strik JJ, Lousberg R, Honig A. Recognizing increased risk of depressive comorbidity after myocardial infarction: looking for 4 symptoms of anxiety-depression. Psychother Psychosom 2006; 75: 346-352.

28. Rutledge T, Linke SE, Krantz DS, Johnson BD, Bittner V, Eastwood JA, Eteiba W, Pepine CJ, Vaccarino V, Francis J, Vido DA, Merz CN. Comorbid depression and anxiety symptoms as predictors of cardiovascular events: results from the NHLBI-sponsored Women's Ischemia Syndrome Evaluation (WISE) study. Psychosom Med 2009; 71: 958-964.

29. Stern RA, Robinson B, Thorner AR, Arruda JE, Prohaska ML, Prange AJ Jr. A survey study of neuro-psychiatric complaints in patients with Graves' disease. J Neuropsychiatry Clin Neurosci 1996; 8: 181-185.

30. Chen Q, Yan Y, Zhang L, Cheng K, Liu Y, Zhu W. Effect of hyperthyroidism on the hypercoagulable state and thromboembolic events in patients with atrial fibrillation. Cardiology 2014; 127: 176-182.

31. Gerding MN, Terwee CB, Dekker FW, Koornneef L, Prummel MF, Wiersinga WM. Quality of life in patients with Graves' ophthalmopathy is markedly decreased: measurement by the medical outcomes study instrument. Thyroid 1997; 7: 885-889.

32. Biondi B, Palmieri EA, Klain M, SchlumbergerM, Filetti S, Lombardi G. Subclinical hyperthyroidism:clinical features and treatment options. Eur J Endocrinol 2005; 152: 1-9.

33. Roset M, Badia X, Mayo NE. Sample size calculations in studies using the EuroQol 5D. Qual Life Res 1999; 8: 539-549.

34. McMurray JJ, Adamopoulos S, Anker SD, Auricchio A, Bohm M, Dickstein K, Falk V, Filippatos G, Fonseca C, Gomez-Sanchez MA, Jaarsma T, Køber L, Lip GY, Maggioni AP, Parkhomenko A, Pieske BM, Popescu BA, Rønnevik PK, Rutten FH, Schwitter J, Seferovic P, Stepinska J, Trindade PT, Voors AA, Zannad F, Zeiher A; ESC Committee for Practice Guidelines. ESC Guidelines for the diagnosis and treatment of acute and chronic heart failure 2012: The Task Force for the Diagnosis and Treatment of Acute and Chronic Heart Failure 2012 of the European Society of Cardiology. Developed in collaboration with the Heart Failure Association (HFA) of the ESC. Eur Heart J 2012; 33: 1787-1847.

35. Mancia G, Fagard R, Narkiewicz K, Redon J, Zanchetti A, Böhm M, Christiaens T, Cifkova R, De Backer G, 
Dominiczak A, Galderisi M, Grobbee DE, Jaarsma T, Kirchhof P, Kjeldsen SE, Laurent S, Manolis AJ, Nilsson PM, Ruilope LM, Schmieder RE, Sirnes PA, Sleight P, Viigimaa M, Waeber B, Zannad F, Redon J, Dominiczak A, Narkiewicz K, Nilsson PM, Burnier M, Viigimaa M, Ambrosioni E, Caufield M, Coca A, Olsen MH, Schmieder RE, Tsioufis C, van de Borne P, Zamorano JL, Achenbach S, Baumgartner H, Bax JJ, Bueno H, Dean V, Deaton C, Erol C, Fagard R, Ferrari R, Hasdai D, Hoes AW, Kirchhof P, Knuuti J, Kolh P, Lancellotti P, Linhart A, Nihoyannopoulos P, Piepoli MF, Ponikowski P, Sirnes PA, Tamargo JL, Tendera M, Torbicki A, Wijns W, Windecker S, Clement DL, Coca A, Gillebert TC, Tendera M, Rosei EA, Ambrosioni E, Anker SD, Bauersachs J, Hitij JB, Caulfield M, De Buyzere M, De Geest S, Derumeaux GA, Erdine S, Farsang C, Funck-Brentano C, Gerc V, Germano G, Gielen S, Haller H, Hoes AW, Jordan J, Kahan T, Komajda M, Lovic D, Mahrholdt H, Olsen MH, Ostergren J, Parati G, Perk J, Polonia J, Popescu BA, Reiner Z, Rydén L, Sirenko Y, Stanton A, Struijker-Boudier H, Tsioufis C, van de Borne P, Vlachopoulos C, Volpe M, Wood DA. 2013 $\mathrm{ESH} / \mathrm{ESC}$ guidelines for the management of arterial hypertension: the Task Force for the Management of Arterial Hypertension of the European Society of Hypertension (ESH) and of the European Society of Cardiology (ESC). Eur Heart J 2013; 34: 2159-2219.

36. Lang RM, Bierig M, Devereux RB, Flachskampf FA, Foster E, Pellikka PA, Picard MH, Roman MJ, Seward J, Shanewise J, Solomon S, Spencer KT, St John Sutton M, Stewart W; American Society of Echocardiography's Nomenclature and Standards Committee; Task Force on Chamber Quantification; American College of Cardiology Echocardiography Committee; American Heart Association; European Association of Echocardiography, European Society of Cardiology. Recommendations for chamber quantification. Eur J Echocardiogr 2006; 7: 79-108.
37. Mosteller RD. Simplified calculation of body-surface area. N Engl J Med 1987; 317: 1098.

38. Scerrino G, Morfino G, Paladino NC, Di Paola V, Amodio E, Gulotta G, Bonventre S. Does thyroid surgery for Graves' disease improve health-related quality of life? Surg Today 2013; 43: 1398-1405.

39. Osman F, Franklyn JA, Holder RL, Sheppard MC, Gammage MD. Cardiovascular manifestations of hyperthyroidism before and after antithyroid therapy: a matched case-control study. J Am College Cardiol 2007; 49: 71-81.

40. Sgarbi JA, Villaca FG, Garbeline B, Villar HE, Romaldini $\mathrm{JH}$. The effects of early antithyroid therapy for endogenous subclinical hyperthyroidism in clinical and heart abnormalities. J Clin Endocrinol Metab 2003; 88: 1672-1677.

41. Hall SA, Cigarroa CG, Marcoux L, Risser RC, Grayburn PA, Eichhorn EJ. Time course of improvement in left ventricular function, mass and geometry in patients with congestive heart failure treated with beta-adrenergic blockade. J Am Coll Cardiol 1995; 25: 1154-1161.

42. Doughty RN, Whalley GA, Gamble G, MacMahon S, Sharpe N. Left ventricular remodeling with carvedilol in patients with congestive heart failure due to ischemic heart disease. Australia-New Zealand Heart Failure Research Collaborative Group. J Am Coll Cardiol 1997; 29: 1060-1066.

\section{*Correspondence to:}

Dacheng Yang

Department of Cardiovasology

Tengzhou Central People's Hospital

No.181, Xingtan Road, Tengzhou 277500, Shandong

PR China 